\title{
ナビゲーションモードに対応した空中撮影 \\ 動画のブレ補正と洪水流計測への適用 \\ IMAGE STABILIZATION OF VIDEO IMAGES SHOOT FROM AIR VEHICLES IN NAVIGATION MODE AND ITS APPLICATION TO FLOOD FLOW MEASUREMENTS
}

\author{
能登谷祐一 $1 \cdot$ 藤田一郎 $2 \cdot$ 建口沙彩 1 \\ Yuichi NOTOYA, Ichiro FUJITA and Saaya TATEGUCHI \\ 1 学生会員 神戸大学大学院工学研究科（广657-8501 神戸市灘区六甲台町1-1) \\ 2 正会員 学術博 神戸大学大学院教授 工学研究科（广657-8501 神戸市灘区六甲台町1-1）
}

The advantage of aerial vehicles in observing various geographic features is its wide field of view, which is different from an observation from the ground. Although the field of view depends on the height of the vehicle and the lens aperture, an area with a side length of more than one hundred meter can be observed at one time. As for measurements of a river reach, a manned helicopter or an unmanned air vehicle has been used to shoot river surface flows, from which surface velocity distributions can be measured by an aerial LSPIV or an aerial STIV techniques developed by our research group. In this paper, a new image stabilizing method was developed for video images shot from navigating aerial vehicles such as a manned helicopter or a UAV. Moreover, the relative accuracy between LSPIV and STIV was discussed for the same aerial videos. The developed method was applied to several new and old videos shot from manned helicopter or an UAV.

Key Words : Flood flow measurement, image stabilization, aerial STIV, UAV, helicopter

\section{1. まえがき}

河川流の映像による観測法には様々な手法がある。最 も簡素な方法は，水面に浮かんだごみ，泡，流木などの 表面浮遊物を目視で観察する方法であり，浮遊速度や浮 遊軌跡を調べることでおよその流れの様子を把握できる この場合，観測地点は川岸であったり，橋の上であった りする.このような浮遊物の速度を定量的に求めるのが マクロ的には浮子法であり，ミクロ的には粒子追随法で ある. 浮子法が流量計測のために数十メートルの河川縦 断区間の平均流速を手動で求めるのに対し，粒子追随法 はPTV(Particle Tracking Velocimetry)とも呼ばれ ${ }^{1,2)}$, 基本 的には連続画像の画像解析によって個々の浮遊物の速度 ベクトル情報が詳細に得られる. 浮子の移動軌跡を追跡 するFloat-PTVのシステム3)も提案されている.

一方，個々の粒子ではなくパターンを追跡する方法が PIV(Particle Image Velocimetry) ${ }^{4,5)}$ である.この場合のパ ターンは, 水表面に浮かんだ浮遊物群, 水面のランダム な凹凸，あるいは河川水の色の違いなどが作り出す河川 表面の模様であり，風の影響が小さければ表面流速で移 動すると考えられる. 河岸から河川表面を斜めに撮影し たビデオ画像を用い，同様の原理で横断流速分布などを
求めるLSPIV(Large-Scale PIV) ${ }^{6,7)}$ も国内外での適用例が多 数ある. 最近では, 主流方向の流速計測に特化した STIV(Space-Time Image Velocimetry) ${ }^{8)}$ が開発され，流量計 測の高度化に寄与している.

ここまでに説明した観測法はいずれも川岸や橋などの 固定点から局所的な河川流を対象とするものであり，非 常に長い河道区間からみればある一断面を詳しくみてい るに過ぎない. 本来の河川は蛇行や分合流などを繰り返 して流下する非常に複雑なシステムであり, 表面流だけ を対象として考えてみても，その全容を把握することは 容易ではない。このような長い河道区間の観測を実現す るには，ローカルリモートセンシング9の技術が有用で ある. 人工衛星のように時間分解能の低いリモートセン シングで河川の速度場を観測することは不可能であるが, 人工衛星ほど高度の高くない地点から河川流を空中ビデ 才撮影すれば，広範囲の流況を把握できるようになる. これまでローカルリモートセンシングで使われてきたの は，飛行機やへリコプターあるいはカイトなどであった が，最近では小型で安定性の高まったいわゆる無人飛行 機（UAV）も利用可能となってきている. 解析手法と しては，空中撮影のブレを補正した画像にPIVやSTIVを

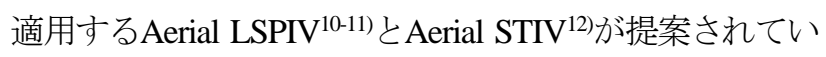


表-1 ローカルリモセン用解析手法の比較

\begin{tabular}{|c|c|c|c|c|}
\hline & \multicolumn{2}{|c|}{ Aerial LSPIV } & \multicolumn{2}{|c|}{ Aerial STIV } \\
\hline 撮影モード & ホバモード & ナビモード & ホバモード & ナビモード \\
\hline 計測時間 & 10秒以上 & 5 10秒程度 & 10秒以上 & 5 10秒程度 \\
\hline 対象画像 & \multicolumn{2}{|c|}{ 数フレーム置きのペア画像 } & \multicolumn{2}{|c|}{ すべての連続画像 } \\
\hline 空間解像度 & \multicolumn{2}{|c|}{ 数m + 数甶四方 } & \multicolumn{2}{|c|}{ 数 $\mathrm{m}$ 十数 $\mathrm{m}$ の線分 } \\
\hline 流速値 & 平均ベクトル & $\begin{array}{l}\text { 瞬間ベクトル } \\
\end{array}$ & \multicolumn{2}{|c|}{ 平均主流方向成分〈検査線方向） } \\
\hline ブレ補正レベル & 要高精度 & ペア画像間のみ & \multicolumn{2}{|c|}{$\begin{array}{c}\text { 要高精度 } \\
\end{array}$} \\
\hline 長所 & $\begin{array}{l}\text { 流向がわかる } \\
\text { 長時間平均値 }\end{array}$ & $\begin{array}{l}\text { 流向がわかる } \\
\text { 長い区間の計測可能 }\end{array}$ & $\begin{array}{l}\text { ノイズに強い } \\
\text { 長時間平均値 }\end{array}$ & 長い区間の計測可能 \\
\hline 短所 & \multicolumn{2}{|c|}{ ノイズに弱い } & 流向が曖昧 & 計測時間に制約有 \\
\hline
\end{tabular}

る. 空中撮影のモードは大別すると，ホバリングモード (略してホバモード) とナビゲーションモード（略して ナビモード）に分けることができる．ホバモードは UAVが視野に入る程度の比較的短い河道区間が対象で あるが，ナビモードは河道沿いを移動撮影するため，数 キロ程度の範囲をカバーできる．ホバモードに対するブ レ補正については前報12)で詳述したので，本研究では主 として新たに開発したナビモードに対する解析手法を提 示し，有人ヘリとUAVで得られた映像に対する適用事 例を紹介する.

\section{2. ナビモードに対するブレ補正}

\section{(1) Aerial LSPIVとAerial STIVの特徵}

ナビモードに対するブレ補正の詳細を記述する前に, ローカルリモセンで用いる $2 つ の$ 手法を表-1に比較した. LSPIV系は，流速ベクトルが得られる点に利点があるが, 既往の研究ではペア画像のブレ補正を画像毎に行う必要 があったため，解析作業にかなりの手間がかかっていた. STIV系は流れ方向に設定した検査線上の輝度分布の時 間変化をすべての連続画像を用いて時空間画像 (STI: Space time image)の形式で表し，STI上に現れる縞パター ンの勾配を求めるため, ブレ補正はかなりの高精度で効 率的に実施する必要がある。また，LSPIV系では，解析 の安定化をはかるためにパターンマッチングのテンプ レートを大きくとる必要が生じ，そのために河岸付近の 流速值が正確には得られない懸念があるが，STIV系で は河岸付近まで計測できる可能性が高い。ただし， STIV系では主流方向が両岸に平行と仮定するために, 大きな湾曲部などでは本来の主流方向と一致しないこと も想定される。この場合は，LSPIV系で求めた流向に 沿って検査線を設定し直すなどの工夫が必要となる.

\section{（2）ナビモードのブレ補正アルゴリズム概要}

アルゴリズムを開発するうえで，ホバモードにはない ナビモードの難しさは，カメラの移動に伴ってリファレ ンス画像（図-1 (a)）とフレーム画像（図-1 (b)）が重な る部分の面積が小さくなっていくところにある. 以降, フレーム画像をFI(Frame Image), リファレンス画像を RI(Reference Image) と略す。ホバモードでは，特徵点抽 出の際に必要となる「RIに対するマスク画像」（図一 2(a)）を作成し，それを変形させることで全ての「FIに 対するマスク画像」の作成を内部処理できたが12)，ナビ

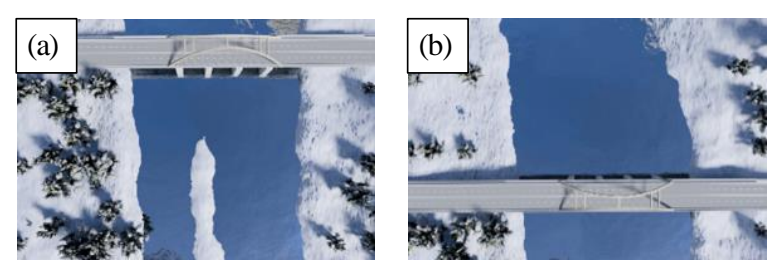

図-1 リファレンス画像 (a) とフレーム画像 (b) の概念図

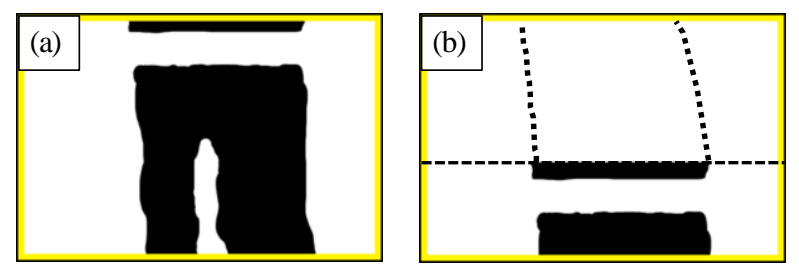

図-2 RIに対するマスク画像(a) とRIから得られるFIlに対す るマスク画像(b)の概念図

モードにこの処理を適用し，図-1 (b) に対するマスク画 像を自動生成することは不可能である，なぜなら，時間 とともに共通の画像域が減少するため，図-1(a)からは 図-2 (b) に示すようなマスク画像しか生成できないため である.

そこで本研究では，解析対象の動画から一旦パノラマ 画像を合成した上で，そこから個々のフレームに対する マスク画像を生成することとした，具体的には，マスク 画像を必要としない手法であるRIPOCによって得られる 相似変換行列によって低い精度のパノラマ画像（図一 3 (a) を作成し，それに対応するパノラママスク画像（図 -3(b)）を作成することで解決を図った。相似変換行列 は式(1)に示す.

$$
\left[\begin{array}{ccc}
a \cos \theta & \sin \theta & b \\
\sin \theta & a \cos \theta & c \\
0 & 0 & 1
\end{array}\right]\left[\begin{array}{l}
x \\
y \\
1
\end{array}\right]=\left[\begin{array}{l}
x^{\prime} \\
y^{\prime} \\
1
\end{array}\right]
$$

ここで $a$ は拡大率， $\theta$ は回転量， $b, c$ はそれぞれ $x$ 軸， $y$ 軸 方向の移動量を表す。 $x, y$ はピクセル座標， $x^{\prime}, y^{\prime}$ は移動 先のピクセル座標である. 開発したブレ補正の手順を要 約すると以下のようになる.

i) RIPOCにより低精度パノラマ画像（図-3(a)）を生成

ii) パノラマ画像に対するマスク画像を作成（図-3(b)）

iii) 上の画像からRIやFIに対応するマスク画像を生成

iv) 特徵点検出アルゴリズムで射影変換行列を算出

v）上の行列を用いて高精度なブレ補正を実施（図-4）

以下では，パノラマ画像の作成手法や特徽点による処 理について詳細に説明する.

\section{（3）パノラマ画像の作成手法}

ナビゲーションモードで想定しているのは，図-3で示 したように，河川部分が中央にあって両側に河岸部が映 しこまれており，機体が河道に沿って移動するような撮 

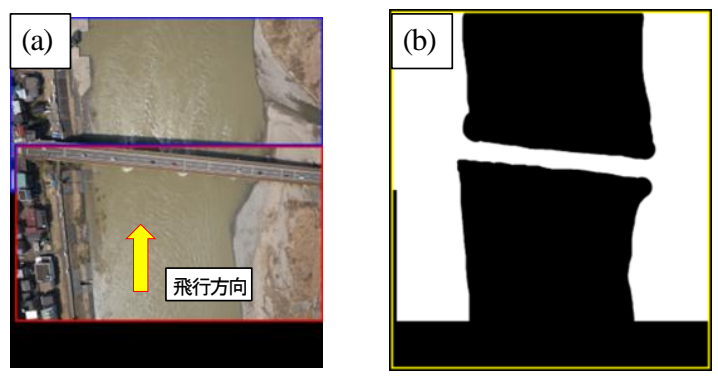

図-3 低精度パノラマ合成画像 (a) と対応するマスク画像(b)

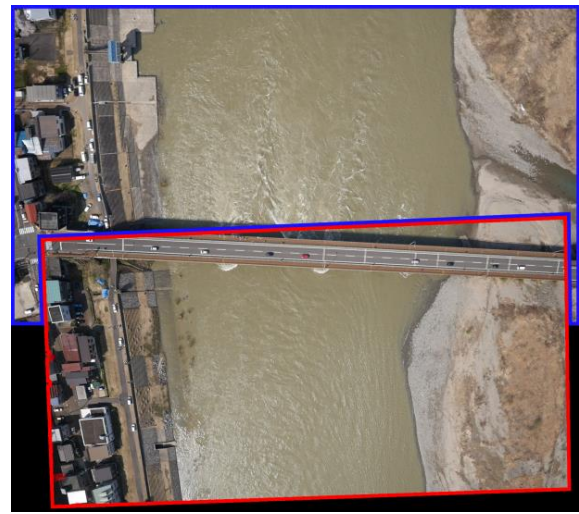

図-4 高精度パノラマ合成画像:赤枠が初期FI, 青枠が 最終FI

影状況である．重要なのは常に両側の河岸が画像内に 入っていることである. 図-5に処理の概要を示している が，まず初期フレーム $\mathrm{FI}_{1}$ を初期リファレンス画像 $\mathrm{RI}_{1}$ に 設定する．添字はFIでは各フレーム番号，RIでは中継回 数を指す. 最初の中継までは, 既報14)のホバモードと同 様に引き続 $<\mathrm{FI}_{2}, \mathrm{FI}_{3}, \cdots$ に対して平行移動量, 回転率, 拡 大率を算出し，相似変換行列により各FIを変形する. そ してリフレーム目に切換え条件に合致したとき， $\mathrm{RI}_{1}$ と $\mathrm{FI}_{l}$ との間の変換行列 $\mathrm{H}_{\mathrm{R} 1}$ を保存し， $\mathrm{FI}_{l}$ を $\mathrm{RI}_{2}$ に置き換える. これが中継であり，切換え条件とは移動による画像の相 対的なずれが画像サイズのある割合に達する条件である。 ここでは， $\mathrm{RI}_{2}$ が中継RIとなる，図-5に示すように，次 の切換え条件に達するまで以降は同様の手順を繰り返す。

一般に中継リファレンス画像RIとFIの間の相似変換行 列をH，初期 $\mathrm{RI}_{1}$ と任意のFIの間の相似変換行列を $\mathrm{A}$ をす ると次式が成立する.

$$
\mathrm{A}=\mathrm{H}_{\mathrm{R} 1} \cdot \mathrm{H}_{\mathrm{R} 2} \cdots \mathrm{H}_{\mathrm{Rn}-1} \cdot \mathrm{H}_{\mathrm{Rn}} \cdot \mathrm{H}
$$

このときのAを用いて任意時点のFIを変形し，パノラマ 画像を作成する．A はパノラママスク画像と各FIに対す る変換行列成分でもあり，各マスク画像は，図-3(b)で 示したパノラママスク画像のデータに対してそのフレー ムに対する $\mathrm{A}^{-1}$ を左からかけることで生成できる.

\section{（4）特徵点の処理}

高精度なブレ補正のための射影変換行列は，2枚の画

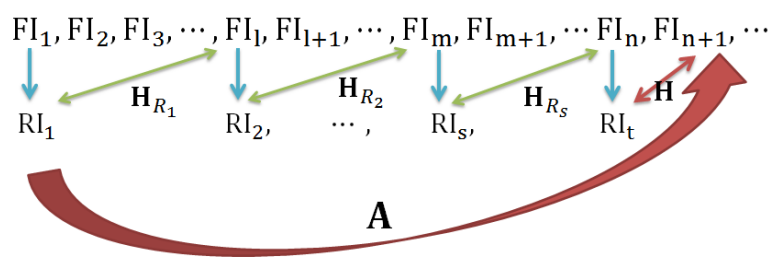

図-5 変換行列の算出

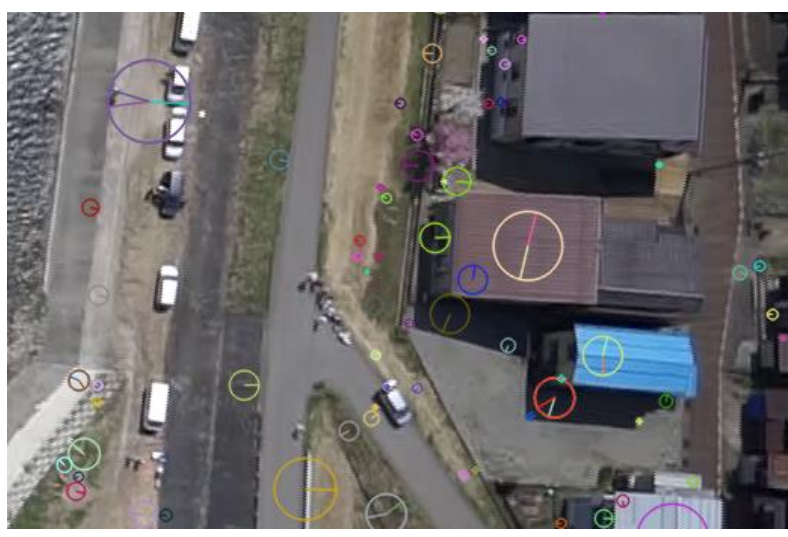

図-6 特徵点抽出とオリエンテーションの検出例

像から特徵的なパターンを持つ点を抽出し，それを対応 付けすることにより算出できる. この処理は「前処理」,

「特徵点抽出」，「特徵量記述」，「対応付け」，「変換行 列の作成」の 5 段階に分けられ, 多くの種類のアルゴリ ズムが開発されている. 本研究では前処理はせず，特徴 点抽出, 特徵量の記述にSIFT, 対応付にはFLANN, 変 換行列の作成にはRANSACの各アルゴリズムを用いた.

図-6には特徵点の抽出状態を示しているが，マッチング の効率を高めるために，式(3)に示すような128次元の特 性を有する特徵量間のユークリッド距離を用いている.

$$
d\left(v^{k p_{R I}}, v^{k p_{F I}}\right)=\sqrt{\sum_{i=1}^{128}\left(v_{i}^{k p_{R I}}-v_{i}^{k p_{F I}}\right)^{2}}
$$

ここでは，リファレンス画像RI中にある特徵点 $k p_{R I}$ とフ レーム画像FI中にある特徴点 $k p_{F I}$ の特徵量ベクトルをそ れぞれ $v^{k p_{R I}}, v^{k p_{F I}}$ としている。この距離が最小とな る特徵点の組み合わせが適切な対応付けの候補となる. さらにRIにおいて抽出された特徴点のFIにおける対応先 はRIPOCによって概算值が算出できる。この概算值は射 影変換性が考慮されていない。概算值を中心とし，閾值

（探査範囲）を半径とする円内にFLANNによって対応 付けされた組み合わせを最も適切な対応付けと判断する.

\section{3. 信濃川洪水流への適用}

\section{(1) 概要}

ここでは，新潟県小千谷市を流れる信濃川の融雪出水 を対象とした解析結果を示す。撮影は，2015年4月24日 


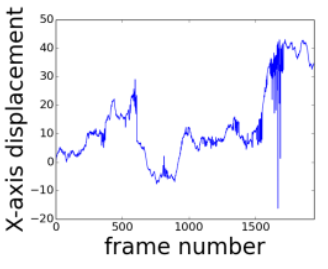

(a) displacement in $\mathrm{x}$ axis

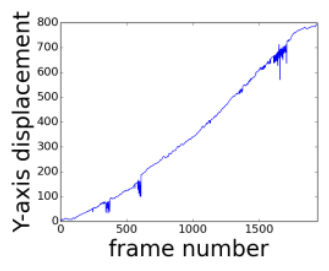

(b) displacement in y axis

図-7 RIPOCIよる平行移動の結果

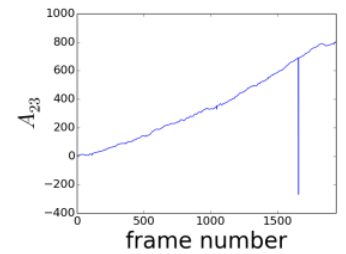

(a) $\mathrm{A}_{23}$

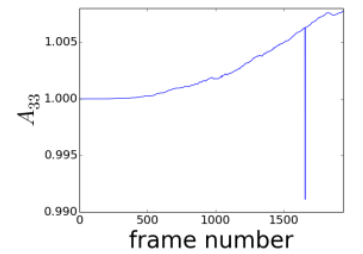

(b) $\mathrm{A}_{33}$
図-8 射影変換行列項の時間変化

に旭橋付近にてカメラを搭載したUAVを飛行させて 行った. 使用したUAVの性能は前報 ${ }^{12)}$ と同様である. 実 際の撮影は様々なアングルで行ったが，本研究ではほぼ 真下を撮影した映像を対象とする。画像サイズは 1920×1080pixel，フレームレートは60fpsである．撮影は 河道区間の様々な地点で行ったが，ここでは旭橋の上下 流を対象としたケースの約30秒間の動画に対寸る解析結 果を示す.ナビモードにおける切換え条件は，フレーム 画像の縦サイズの $8 \%$ を超えて移動したときとした. FLANNにおける探查範囲は15Pixelとした.

\section{（2）RIPOCにによる概算値の算出}

ナビモードの解析状態を示寸ために，RIPOCによって 得られるパラメータのうち $x$ 軸, $y$ 軸方向の移動量を図 -7 に示した．撮影時間約 30 秒間に $y$ 軸方向にフレームが 800Pixel程度移動していることがわかる.この結果を用 いて生成した低精度パノラマ画像が図3(a)であるが，こ の段階では右岸のつなぎ目が若干不連続になっているこ とがわかる.

\section{（3）特徵点処理による高精度な射影変換行列の算出}

射影変換行列 $\mathrm{A}$ の成分のうち $\mathrm{A}_{23}$ と $\mathrm{A}_{33}$ の推移を図-8に 示す. $\mathrm{A}_{33}$ の值は本来常に1となるパラメータであるが, 時間経過とともに若干 1 からずれてきている。これは実 像の 3 次元性が一因である. 寸なわち図 1 の橋梁のよう に, カメラの移動に従って像の写り方が変化することで, 厳密に正確な変換行列を作成することが困難になるので ある. RIを中継するほどこの誤差が蓄積される恐れも高 くなるが，信濃川のこの例では誤差は最大 0.008 と小さ く解析結果への影響は無視できる． $\mathrm{A}_{23}$ の值は射影変換 性が小さいという仮定の下ではy軸方向移動量に大きく 寄与寸る. 図-7 (b) のRIPOCの結果と比べて滑らかな推

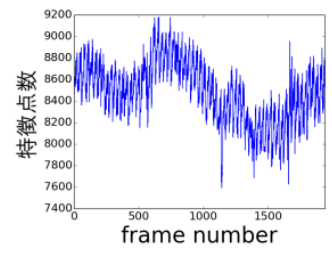

(a)特徴点数

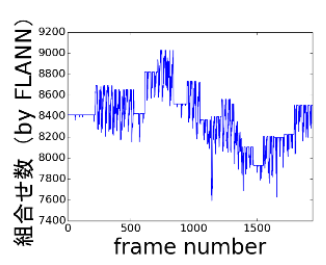

(b)FLANNによる組合せ数
図-9 特徵点の抽出結果

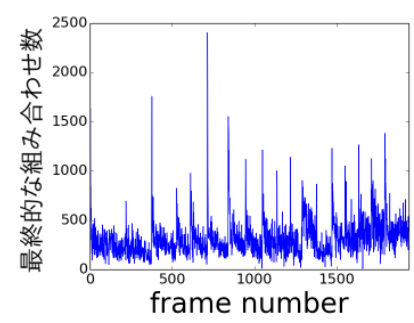

図-10 最終的な組み合わせ数
移であり，精度が改善されていることがわかる.

図-9 (a) は各フレームにおいて抽出されたSIFT特徽点 数で, およそ8500個の特徵点を安定して抽出している. 図-9(b) はFLANNによって対応付けされた組み合わせ数 であるが，RIが中継によって切り替わるので階段状に なっている. 本ケースでは17回の中継が行われている. 図-10はRIPOCによる概算值を用いて除外し，RANSAC によって最終的に使われた組み合わせである. 中継時前 は射影変換性が弱く，多くの組み合わせが残るが，平均 的には200〜300個の有意なペアが検出されている.

\section{(4)結果と考察}

以上に詳述したナビゲーションモードによる河川映像 のブレ補正動画を用いて, 河川表面流の解析を行った. 得られた動画における 1 画素サイズは $0.155 \mathrm{~m}$ であった が，この值は地図との比較あるいは堤防上に設置したい くつかの標定点座標間距離から求めた. 図-11に示した のはAerial STIVによる結果である，検査線は長さ25.7m， 間隔は $3.0 \mathrm{~m}$ とし, 河岸に平行に設定した. 解析に使用 した画像枚数は600枚である. 融雪出水のため接近流速 が大きかったこともあり, 旭橋の各橋脚間で流れが加速 し，橋下流では図-11中の写真に示すように水面が大き く変動すると同時に大量の気泡が流れに混入した複雑な 流れ場が形成されていた．本観測では各タイプのADCP による計測も行われていたが，小型のボートは頻繁に転 覆し計測は困難であった。これに対し, 高度約 $200 \mathrm{~m}$ か ら撮影した映像を用いた画像解析では水面変動の影響は 見られず, 橋脚間で加速され, 橋脚背後の後流域で減速 する特徵的な流速分布が得られた．ただし，橋上流の右 岸近くでは徐々に水深が浅くなっており, 主流部の水面 変動で生じた波が河岸に向かって伝播していたために, 主流方向に検查線を設定したSTIはあまり鮮明ではなく， 得られた流速值には若干の誤差が含まれると思われる. 


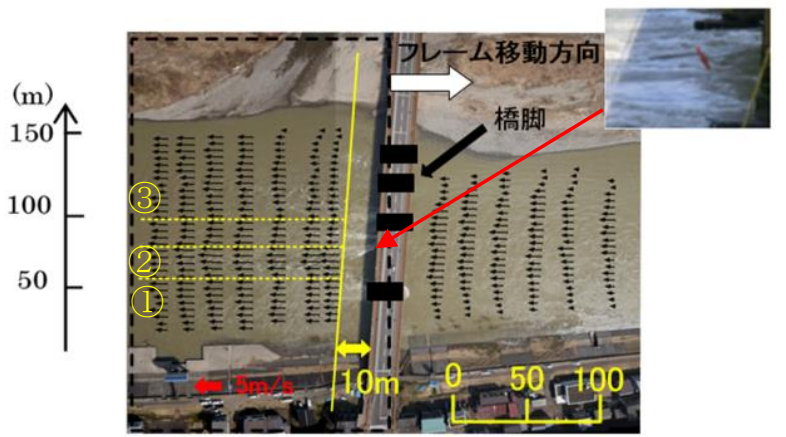

図-11 Aerial STIVIよる表面流速分布 : 右上写真は 旭橋下流の状態 : 小型ボートは転覆, 水面の波高は $1 \mathrm{~m}$ 以上 (点線の枠は1画素サイズ)

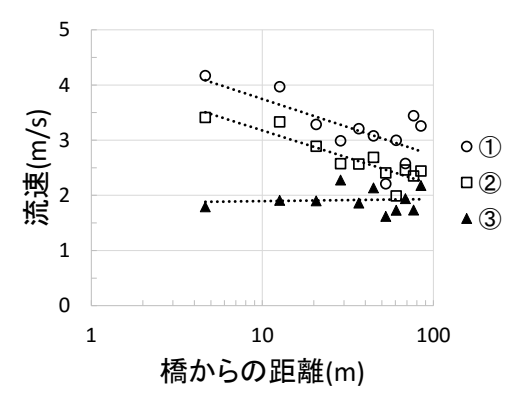

図-12 橋下流の縱断測線上のSTIVIによる流速分布 : (1)は左岸から55m，21は86m，3は100mの縱断測線

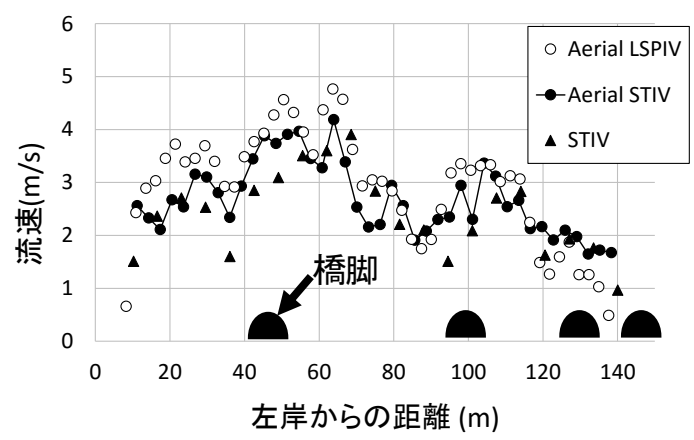

図-14 橋下流約 $10 m$ の横断測線上の流速分布の比較

図-12には，左岸寄りの $2 つ の$ 橋脚間に設定した緹断 測線（橋から5～85m間）における表面流速の縦断変化 を片対数プロットした．加速域のデータ (1)と (2) は片 対数紙上で直線的に減衰し，下流でほぼ同じ流速に収束 している，一方，(3の減速域下流では，逆にわずかに流 速值の回復が見られるが，(1)や(2)の測線とは差があり， 橋脚による流れの影響がかなりの下流域にまで及んでい ることがわかる.

図-13は同じ範囲をAerial LSPIVによって解析した結果 である。テンプレートサイズは $14 \times 14 \mathrm{~m}$ ，画像間隔は 0.08秒とした。 流速值は若干ばらついているが，橋脚通 過流の加速の様子や橋脚後流で流れが集中している様子 がよくわかる．流速ベクトルの集中はSTIVでは簡単に は得られない特徴である. 図-14は橋の直下流約 $10 \mathrm{~m} の$ 横断測線における流速分布を 3 手法で比較したものであ

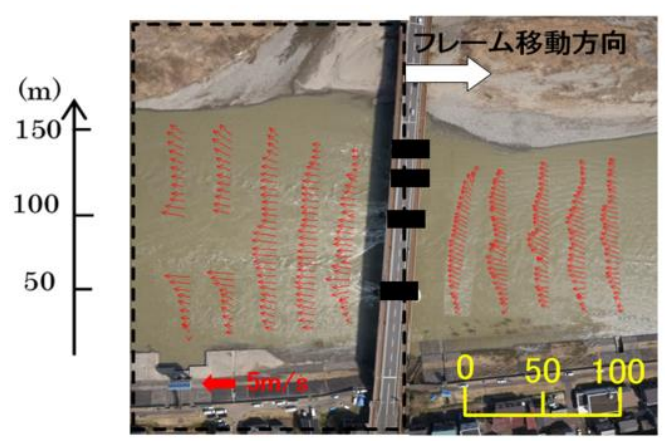

図-13 Aerial LSPIVIによる表面流速分布 (点線の枠は1画素サイズ)

る.ここでSTIVは，河岸設置のビデオカメラで撮影し た斜め画像から求めた結果である。 3 手法とも, 同様の 分布を与えているが，STIVは水面の起伏が激しい地点 での值に若干のずれが見られる，現地ではADCPによる 計測も行われているが，最大流速はほぼ一致することを 確認している.

\section{4. 揖保川洪水流への適用 \\ (1) 概要}

ここでの対象は兵庫県を流れる揖保川で2009年に発生 した洪水である. このときの撮影は有人へリコプターで 行われたが，水面に多数の定在波が生じていたため解析 を断念していた古い動画が解析の対象である. 動画はサ イズが1920×1080pixel，フレームレートが30fpsである. 解析画像枚数は300枚であるが, へリの速度は速く, 約 10秒間で対象とする長さ約 $300 \mathrm{~m}$ の湾曲部を通過した. 機体の振動も大きく, ナビモードで扱える動画としては クオリティの低いものであった. 加えて, 対象域は河岸 に植生が繁茂し，樹林で覆われた山が近接している。こ のような植物に起因する画像上のパターンはごの点をみ ても, 類似な模様が多く, 信濃川で適用できたアルゴリ ズムだけでは有意な特徴点マッチングが困難であった.

そこで, 本ケースの場合はリファレンス画像を中継す るタイミングを $5,10,20$ フレーム毎と分類し，補正の難易 度に応じてタイミングを変えた. 信濃川においての議論 から，リファレンス画像に近いフレームは対応付けでき る組み合わせ数が多いことから頑健性が増寸分, 中継回 数分の誤差が蓄積される懸念も増える. したがって, 5 フレーム毎とする解析範囲においては左岸の高い樹木部 分について特徴点数を少なくするよう強くマスク画像で 制限し，10,20フレームごとの部分は弱く制限した（図15）。強く制限するほど似たパターンが散在している影 響による誤った対応付けのリスクは減るが，適切な対応 付けがなされる組み合わせ数も減少させてしまう恐れが あり，トレードオフの関係となる，なお，FLANNにお ける探查範囲は15pixelとした。 


\section{（2）結果と考察}

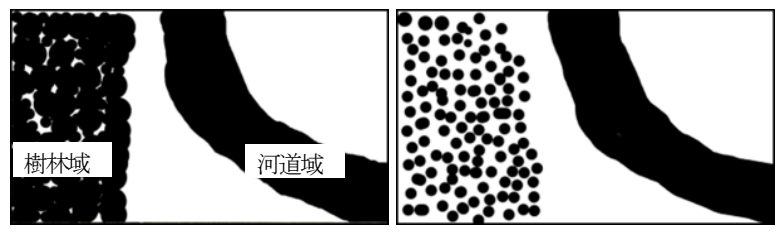

図-15 マスク画像による強い制限 (左) と弱い制限 (右)

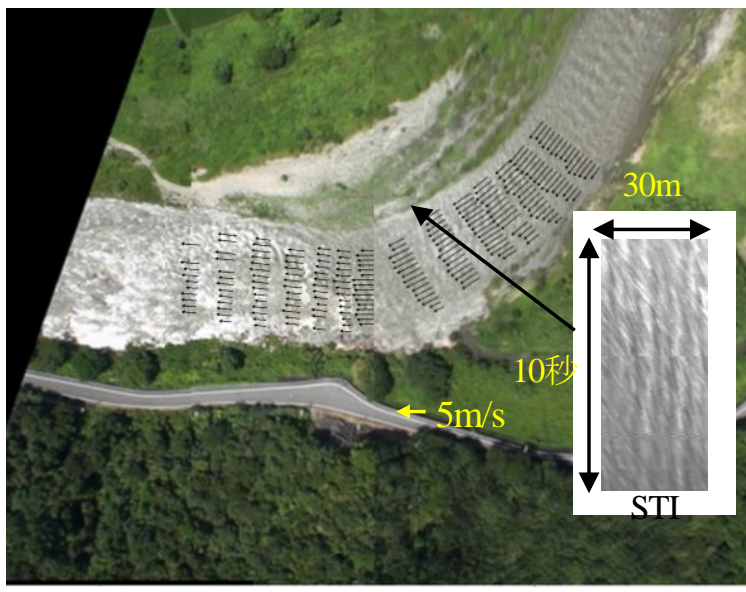

図-16 Aerial STIVIよる解析結果とSTI例

対象地点の揖保川の特徵は大きく湾曲した流路にある。 図-16にAerial STIVによる表面流速分布の解析結果を示 すが，湾曲部前の直線部では流速が $5 \mathrm{~m} / \mathrm{s}$ 程度と大きいの に対し，湾曲後は流速が低下している．この地点は，湾 曲頂部付近に高低差が2 $\mathrm{m}$ 程度の自然の段落ちが発生して おり，上下流で流況が異なるためにこのような変化が表 れている. Aerial STIVによる結果はこの様子をよく捉え ている．図-16からもわかるように湾曲部上流では水面 に定在波が生じていたため, Aerial LSPIVでは解析が困 難であった。ただし，図中に示すように時空間画像 (STI) 上には，定在波を示寸縦のパターンに加えて斜め 方向の波紋の移流を示寸パターンが現れており，このパ ターン勾配を検出できることから定在波がある場合でも 表面流速の計測が可能となった．ただし，検査線は河岸 に平行にとったため, 流向に関しては不明な点もある.

\section{5. あとがき}

本研究では河川に沿って移動飛行する機体から効率的 に空間的な表面流速分布の算出を行うアルゴリズムを開 発し，実河川への適用と既往の手法との比較からその検 証を行った．移動飛行して撮影し，動体が画像中の大き な面積を占める映像に対して，標定点を設置せず効率的 にフレーム画像の位置合わせを行った例はほとんどなく， 洪水災害時の流れの解析やシミュレーションの検証に大 変有用であると考えられる。一方で斜め方向の角度を 持って移動した映像への適用には未だ課題がある.さら に日射方向，天候条件によって水面のパターンが見えづ
らい状況や撮影困難な状況となる懸念がある.今後は本 手法の適用を多様な条件一拡大していくと共に, 最適な 撮影状況の検討や頑健性の向上をはかりたい.

\section{謝辞}

本研究は，土木学会水工学委員会の流量観測技術高度 化小委員会と土木研究所の合同観測の成果であるが，観 測は参加していただいた数多くの方々の協力によって実 現できた．特にルーチェサーチ社にはUAVの提供と撮 影をして頂いた．ここに記して謝意を表します。

\section{参考文献}

1) Lloyd, P.M., Stansby, P.K. and Ball, D.J.: Unsteady surface-velocity field measurement using particle tracking velocimetry, Journal of Hydraulic Research, 33 (4), pp.519-534, 1995.

2) Admiraal, D., Stansbury, J., and Haberman, C.: Case study: particle velocimetry in a model of Lake Ogallala, Journal of Hydraulic Engineering, 130 (7), 599-607, 2004.

3) http://www.be-system.co.jp/navi_soft/soft_kustiv/kustiv.htm

4) Raffel, M., Willert, C., Wereley, S. and Kompenhans, J.: Particle Image Velocimetry - A Practical Guide, Springer, 2007.

5) Adrian, R.J. and Westerweel, J.: Particle Image Velocimetry, Cambridge, 2011.

6) 藤田一郎・河村三郎：ビデオ画像解析による河川表面流計 測の試み, 水工学論文集, Vol.38,pp.733-738, 1994.

7) Muste, M., Fujita, I., and Hauet, A.: Large-scale particle image velocimetry for measurements in riverine environments, Water Resources Research 44, W00D19, doi:10.1029/2 2008WR006950, 2008.

8) Fujita, I., Watanabe, H. and Tsubaki, R.: Development of a nonintrusive and efficient flow monitoring technique: The space time image velocimetry (STIV), Internatio nal Journal of River Basin Management, 5 (2), pp.105-114, 2007.

9) 江藤剛冶 - 竹原幸生 - 高野保英 - 奥野訓史 - 藤田一郎 - 酒 井信行 : ローカルリモートセンシングによる河川表面流の P T V計測の試み, 土木学会論文集, No.796/II-72,pp.39-52, 2005.

10) Fujita, I. and Kunita, Y.: Application of aerial LSPIV to the 2002 flood of the Yodo River using a helicopter mounted high density video camera, Journal of Hydro-environment Research, 5(4), pp.323-331, 2011.

11) Detert, M. and Weitbrecht, V.: A low-cost airborne velocimetry system: proof of concept, Journal of Hydraulic Research, DOI: 10.1080/00221686.2015.1054322, 2015.

12) 藤田一郎・能登谷祐一・霜野 充:マルチコプターから撮影 されたブレ動画の高精度補正に基づく Aerial STIVの開発,土木学 会論文集B1(水工学),Vol.71, No.4, I_829-I_834, 2015.

(2015.9.30受付) 